\title{
DPF's Regeneration Procedures and Emissions with RME Blend Fuels
}

J. Czerwinski, S. Bürki, P. Bonsack, University of Applied Sciences, Biel-Bienne, Switzerland (AFHB)

\author{
A.Mayer \\ TTM, Switzerland \\ P. Dimopoulos, N. Heeb \\ EMPA, Switzerland \\ G. D'Urbano \\ BAFU, Switzerland \\ S. Hermle, S. Renz \\ BfE, Switzerland
}

Copyright (c) 2012 SAE International

\begin{abstract}
The fatty acid methyl esters (FAME's) - in Europe mostly RME (Rapeseed methyl ester) - are used in several countries as alternative biogene Diesel fuels in various blending ratios with fossil fuels (Bxx). Questions often arise about the influences of these biocomponents on the modern exhaust aftertreatment systems and especially on the regeneration of Diesel particle filters (DPF).

In the present work different regeneration procedures of DPF systems were investigated with biofuels B0, B20 \& B100.

The tested regeneration procedures were:

- $\quad$ passive regenerations: DOC + CSF; CSF alone,

- $\quad$ active regenerations: standstill burner; fuel injections \& DOC.

During each regeneration on-line measurements of regulated and unregulated emission components (nanoparticles \& FTIR) were conducted.

It can be stated that the increased portion of RME in fuel provokes longer time periods to charge the filter with soot. This is due to the lower PM-emissions of the engine, as well as to the higher reactivity and higher SOF-portion of the particle mass from RME.

With the passive regeneration system with stronger catalytic activity (DOC $+\mathrm{CSF}$ ) there is a stronger $\mathrm{NO}_{2}$-production with $\mathrm{B} 100$ and due to the $\mathrm{NO}_{2}$-supported oxidation of $\mathrm{PM}$ the balance point temperature is approx. $20^{\circ} \mathrm{C}$ lower, than with $\mathrm{B} 0$.

For the active regenerations the time histories of emissions and temperatures are closely connected with the chosen regeneration strategy - switching, timing and intensity (of burner, or fuel aerosol generator).
\end{abstract}

A higher portion of biocomponent usually causes a stronger break-down of the instantaneous DPF filtration efficiency during the regeneration procedure - this is an effect of stronger artefact of spontaneous condensation after DPF.

In summary there is no negative short term effect of bio-blend-fuels on the investigated regeneration procedures. Some recommendations for a successful long term operation, basing on other works and literature are given at the end of the paper.

\section{INTRODUCTION}

The passive $\mathrm{DPF}^{*}$ ) regenerations by means of catalytically coated DPF's (CSF ... catalyzed soot filter), or a combination of oxidation catalyst (DOC) upstream and a CSF downstream are preferred for retrofitting as simplest solution, if the conditions of engine operation allows it. Especially the engine application has to result in sufficient frequency of higher exhaust gas temperatures, which enable the light-off and sufficient duration of the catalytic oxidation of the collected particle mass. The low sulphur content of the fuel and the appropriate lube oil quality have to guarantee the long-duration efficiency of the catalytic coatings.

Active regeneration of DPF with burner has an advantage to be independent of engine operating conditions, catalytic coatings and fuel quality. It can be applicable for difficult situations, like low load operation with high sulfur fuel.

${ }^{*}$ Abbreviations see at the end of this paper 
Regeneration with fuel injection (fuel aerosol generator) and oxidation catalyst (DOC) also offers the advantages of being mostly independent of engine operating conditions, but with the restriction of exhaust gas temperature, which has to be above the lightoff temperature of the DOC. The catalytically supported fuel oxidation requires low sulfur fuels to enable the necessary long life of the catalytic coating.

In the present work the studies about the passive and active regeneration procedures were performed with different bio-contents $\mathrm{B} 0, \mathrm{~B} 20$ \& B100.

\section{FAME'S AND DPF REGENERATION}

Short literature survey about influences of FAME's on the Diesel exhaust gas aftertreatment, soot oxidation \& structure is given in this section:

The impact of blending 20\% SME (soy methyl ester) to Diesel fuel on the regeneration of a catalyzed DPF was investigated in [1] (US) on a Cummins 6 cyl. 5.9L engine. The tools used were: the traditional engine diagnostics for injection, combustion and limited emissions, as well as analytics of soot composition and structure. It was shown, that biodiesel blending alters the composition of the particulate matter (PM), as well as the nanostructure of the primary soot particles and thereby alters the regeneration behaviour of DPF. The inclusion of biodiesel in the base fuel reduces the temperature required to initiate the regeneration. This is attributed to the changed nanostructure and oxidation reactivity of the primary soot particles, yielding a more amorphous soot structure, which enhances the soot oxidation.

In [2], the same researchers group focused on the mechanisms of oxidation of biofuel soot (B100, SME) and confirmed that due to different structure and oxygen content the B100 soot is more reactive and undergoes a different oxidation process, than the soot derived from Diesel fuel (ULSD \& FT). By means of partial oxidations and a detailed analysis of soot structure it was shown that the crucial mechanism by which biodiesel soot enhances oxidation is a structural transformation of the surface of the soot conglomerates in the early stage of oxidation, whereby the initial surface oxygen groups are more important than the initial structure and pore size distribution.

In [3] the effects of biodiesel blends (B20 \& B100, SME) were investigated on a Cummins engine 5.9L with a catalyzed CRT (continuously regenerating trap). Significant lowering of the balance point temperature $\left(\Delta \mathrm{t} 45^{\circ} \mathrm{C}\right.$ with $\mathrm{B} 20, \Delta \mathrm{t} 112^{\circ} \mathrm{C}$ with $\left.\mathrm{B} 100\right)$, as well as an increase of regeneration rate was found. If it would be possible to renounce active regeneration systems due to the use of biofuels, this would mean a supplementary energy saving.

Also Finnish researchers, [4], investigated B50 \& B100 (seed oils methyl ester) on two engines, and found differences in morphology (SEM), differences in chemistry and easier passive regeneration of DPF with biocomponents. It is suggested that potassium contained in the investigated oils might assist in formation of inorganic substances, which would catalytically lower the ignition temperature of the soot. Nevertheless it has to be remarked, that the alkali metals have a negative long-term effect on the ceramic substrates of aftertreatment devices [11] and also see the comments in the Remarks and Recommendations section at the end of this paper.

German researchers, [5], give an extensive overview of different alternative fuels for Diesel engines (except for FAME, also dimethyl ether (DME) and synthetic fuels (xTL)). There is also an overview of exhaust gas aftertreatment systems. Important statements are given about the risks of deactivation of catalysts (thermal, chemical \& mechanical deactivation effects), which is known from several experiences with biofuels in the past. The limiting of impurities and phosphorus in biofuels according to the present standards is an obligatory prerequisite for successful operation.

\section{TEST-ENGINE, FUELS AND LUBRICANT}

\section{The main data of the test engine are:}

Manufacturer:

Type:

Cylinder volume:

Rated RPM:

Rated power:

Model:

Combustion process:

Injection pump:

Supercharging:

Emission control:

Development period:
Liebherr Machines Bulle S.A., Bulle/Fribourg

D934 S

6.36 Liters

$2000 \mathrm{~min}^{-1}$

$105 \mathrm{~kW}$ (ECU setting)

4 cylinder in-line

direct injection

Bosch unit pumps

Turbocharger with intercooling

none (exhaust gas aftertreatment according to the requirements)

2005 
Fig. 1 shows the engine and the apparatus for nanoparticle analytics SMPS \& NanoMet in the laboratory for IC-engines, University of Applied Sciences, Biel-Bienne.

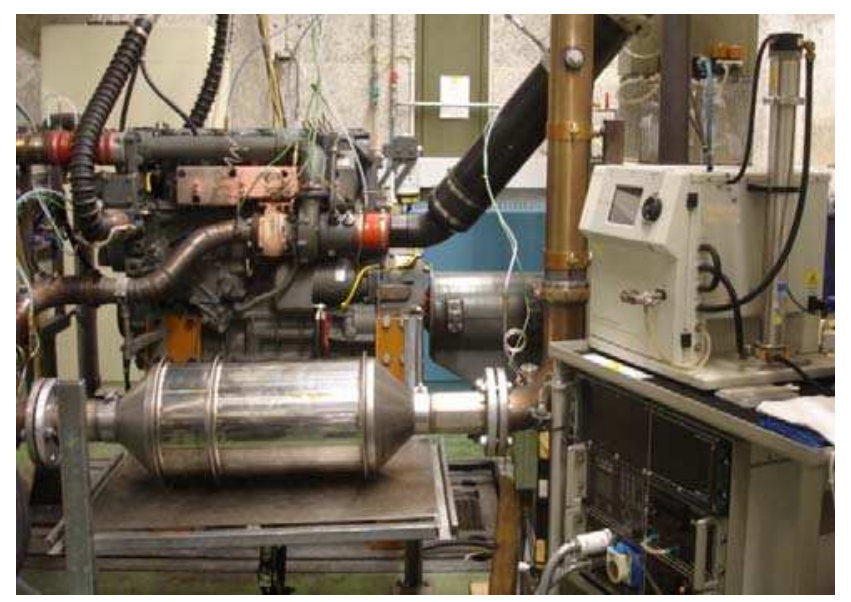

Figure 1 - Liebherr engine D934 S and equipment for nanoparticle measurements in the engine room

\section{Fuels}

Following base fuels were used for the research (Table 1):

- Shell Formula Diesel fuel Swiss market summer quality (10 ppm S) according to SN EN 590

- $\quad$ Rapeseed Oil Methyl Ester RME from Flamol, Berne, $\mathrm{CH}$

Table 1 - Fuel properties as per EU-standards and further analysis of the test fuels

\begin{tabular}{|lc|c|c|}
\hline & & Diesel & RME \\
\hline Density at $15^{\circ} \mathrm{C}$ & $\mathrm{g} / \mathrm{ml}$ & $0.832^{*}$ & $0.885^{*}$ \\
\hline Viscosity at $40^{\circ} \mathrm{C} \quad \mathrm{mm}^{2} / \mathrm{s}$ & $2.0-4.5$ & $4.6^{*}$ \\
\hline Flash point & & Above & $143^{\circ} \mathrm{C}$ \\
\hline Cloud point & & $\max -10^{\circ} \mathrm{C}$ & - \\
\hline Filterability CFPP & & $\max -20^{\circ} \mathrm{C}$ & -15 \\
\hline Ash & $\mathrm{ppm}$ & $<10$ & $1.3 *$ \\
\hline Sulfur & & 51 & 56 \\
\hline Cetane Number & $\mathrm{MJ} / \mathrm{kg}$ & 42.7 & 37.2 \\
\hline Calorific value & in $\%$ & 86.7 & 77.5 \\
\hline C fraction & in $\%$ & 13.3 & 11.8 \\
\hline H fraction & in $\%$ & 0 & 10.7 \\
\hline O fraction & $\mathrm{kg} / \mathrm{kg}$ & 14.52 & 12.49 \\
\hline Air ${ }_{\text {min }}$ & & $180-340$ & $315-360$ \\
\hline \multicolumn{2}{|r|}{ Boiling range $10-90 \%{ }^{\circ} \mathrm{C}$} & $*$ external analysis
\end{tabular}

Table 1 represents the most important data of the fuels according to the standards and the analysis certificates.

It can be remarked, that there are differences of density, heat value, stoichiometric air requirement and boiling range, which have influences on the engine operation and especially on the full load parameters. These fuel parameters, which change with different biocomponent blending ratio, are taken into account by the evaluation of the measurements. 
The resulting fuel parameters for the blend fuels are represented in Table 2:

Table 2 - Principal parameters of the blend fuels

\begin{tabular}{|l|l|l|l|}
\cline { 2 - 4 } \multicolumn{1}{c|}{} & $\begin{array}{l}\rho\left(\mathbf{2 0}^{\circ} \mathbf{C}\right) \\
{\left[\mathbf{k g} / \mathbf{d m}^{3}\right]}\end{array}$ & $\begin{array}{l}\mathbf{H}_{\mathbf{u}} \\
{[\mathbf{M J} / \mathbf{k g}]}\end{array}$ & $\begin{array}{l}\mathbf{A i r}_{\text {min }} \\
{\left[\mathbf{k g}_{\mathbf{A}} / \mathbf{k g} \mathbf{~}\right]}\end{array}$ \\
\hline Diesel & 0.832 & 42.70 & 14.52 \\
\hline RME 20 & 0.842 & 41.55 & 14.10 \\
\hline RME 100 & 0.880 & 37.20 & 12.49 \\
\hline
\end{tabular}

\section{Lubricant}

Lubrizol research oil OS No. 165108, blue, $15 \mathrm{~W} / 40$

Table 3 - Data of lubricating oil

\begin{tabular}{|l|c|c|}
\hline Property & & \\
\hline Viscosity kin $100^{\circ} \mathrm{C}$ & 13.98 & $\mathrm{~mm}^{2} / \mathrm{s}$ \\
\hline Pourpoint & -25 & ${ }^{\circ} \mathrm{C}$ \\
\hline Total Base Number TBN & 8.4 & $\mathrm{mg} \mathrm{KOH} / \mathrm{g}$ \\
\hline Sulfur ashes & 10770 & $\mathrm{mg} / \mathrm{kg}$ \\
\hline Sulfur & 3360 & $\mathrm{mg} / \mathrm{kg}$ \\
\hline $\mathrm{Mg}$ & $<10$ & $\mathrm{mg} / \mathrm{kg}$ \\
\hline $\mathrm{Zn}$ & 1200 & $\mathrm{mg} / \mathrm{kg}$ \\
\hline $\mathrm{Ca}$ & 2630 & $\mathrm{mg} / \mathrm{kg}$ \\
\hline $\mathrm{P}$ & 1110 & $\mathrm{mg} / \mathrm{kg}$ \\
\hline
\end{tabular}

\section{MEASURING SET-UP \& INSTRUMENTATION}

\section{Engine dynamometer and standard test equipment}

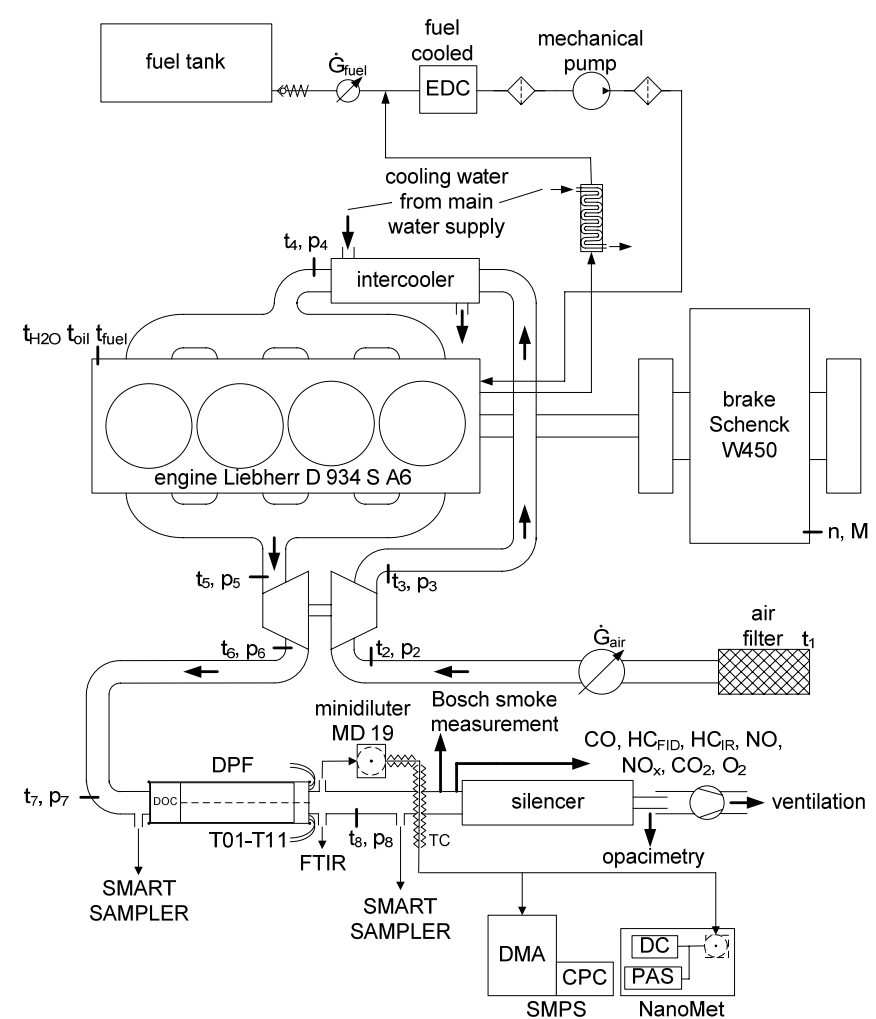

Figure 2 - Engine dynamometer and standard test equipment 


\section{TEST EQUIPMENT FOR EXHAUST GAS EMISSIONS}

The measurement is performed according to the Swiss exhaust gas emissions regulation for heavy duty vehicles (Directive $2005 /$ 55 / ECE \& ISO 8178):

- Volatile components:

- Horiba exhaust gas measurement devices

Type VIA-510 for $\mathrm{CO}_{2}, \mathrm{CO}, \mathrm{HC}_{\mathrm{IR}}, \mathrm{O}_{2}$,

Type: Eco Physics CLD 822 for NO, $\mathrm{NO}_{x}$

- Amluk exhaust gas measurement device Type FID 2010 for $\mathrm{HC}_{\mathrm{FID}}$,

- FTIR (Fourier Transform Infrared) Spectrometer (AVL SESAM) with possibility of simultaneous, time-resolved measurement of 25 emission components - among others: $\mathrm{NO}, \mathrm{NO}_{2}, \mathrm{NO}_{\mathrm{x}}, \mathrm{NH}_{3}, \mathrm{~N}_{2} \mathrm{O}, \mathrm{HCN}, \mathrm{HNCO}$.

\section{PARTICLE COUNTS \& SIZE ANALYSIS}

To estimate the filtration efficiency of the DPF, the particle size and counts distributions were analysed with following apparatus, see Fig. 1:

- $\quad$ SMPS - Scanning Mobility Particle Sizer,

- NanoMet - System consisting of:

- $\quad$ PAS - Photoelectric Aerosol Sensor

- $\quad$ DC - Diffusion Charging Sensor

- $\quad$ MD19 tunable minidiluter - heated up to $80^{\circ} \mathrm{C}$

Thermoconditioner (TC) (i.e. MD19 + postdilution sample heating up to $300^{\circ} \mathrm{C}$ ).

\section{TESTED DPF SYSTEMS}

For the research of impacts of the biocomponents on the DPF regeneration four DPF systems were supplied.

Some data of the systems are summarized in Table 4, Figures $3 \& 4$ show two of the DPF systems mounted on the test engine.

Table 4 - Investigated DPF systems

\begin{tabular}{|c|c|c|c|c|}
\hline $\begin{array}{l}\text { DPF } \\
\text { System }\end{array}$ & Supplier & DOC & DPF & $\begin{array}{l}\text { Regene- } \\
\text { ration }\end{array}$ \\
\hline \multicolumn{5}{|c|}{ Passive regeneration } \\
\hline $\mathrm{DOC}+\mathrm{CSF}$ & $\begin{array}{l}\text { HUG } \\
\text { AG }\end{array}$ & $\begin{array}{l}\mathrm{Pt}, 1.9 \mathrm{~L} \\
\mathrm{SiC} \\
\varnothing 151 \times 120\end{array}$ & $\begin{array}{l}\mathrm{V}, 4.9 \mathrm{~L} \\
\mathrm{SiC} \\
\varnothing 151 \times 300\end{array}$ & CRT \\
\hline CSF & $\begin{array}{l}\text { HUG } \\
\mathrm{AG}\end{array}$ & - & $\begin{array}{l}\mathrm{V}, 4.9 \mathrm{~L} \\
\mathrm{SiC} \\
\varnothing 151 \times 300\end{array}$ & cDPF \\
\hline \multicolumn{5}{|c|}{ (Semi)active regeneration } \\
\hline MK & $\begin{array}{l}\text { HUSS } \\
\text { GmbH }\end{array}$ & - & $\begin{array}{l}\mathrm{SiC} 5.8 \mathrm{~L} \\
\varnothing 210 \times 203\end{array}$ & $\begin{array}{l}\text { standstill } \\
\text { burner }\end{array}$ \\
\hline MD & $\begin{array}{l}\text { HUSS } \\
\text { GmbH }\end{array}$ & $\begin{array}{l}\mathrm{Pt} / \mathrm{Pol}, \\
4.3 \mathrm{~L} \\
\text { Cordierite } \\
\varnothing 190 \times 152\end{array}$ & $\begin{array}{l}\mathrm{SiC}, 5.8 \mathrm{~L} \\
\varnothing 210 \times 203\end{array}$ & $\begin{array}{l}\text { fuel } \\
\text { aerosol } \\
\text { generator } \\
+ \text { DOC }\end{array}$ \\
\hline
\end{tabular}

All applied filter materials were SiC (silicon carbide) with a high average filtration efficiency PCFE $>99 \%$ fulfilling the VERT / OAPC quality criteria. 


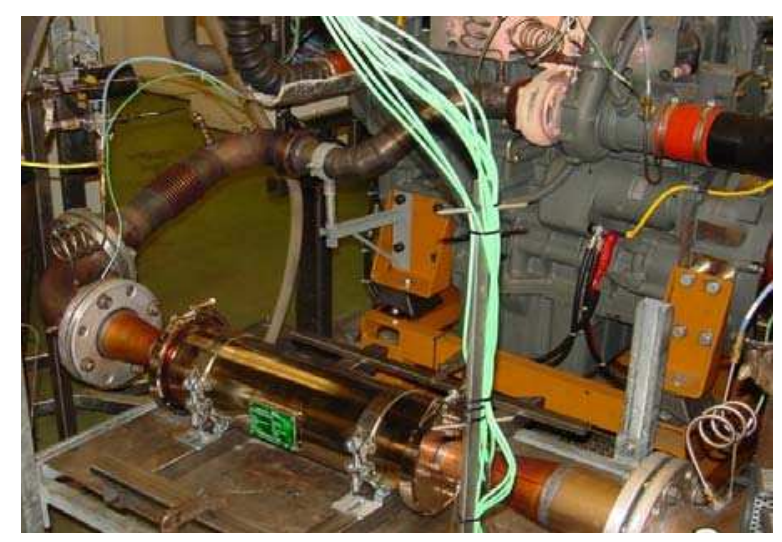

Figure 3 - DPF with passive regeneration (DOC+CSF) on the Liebherr engine

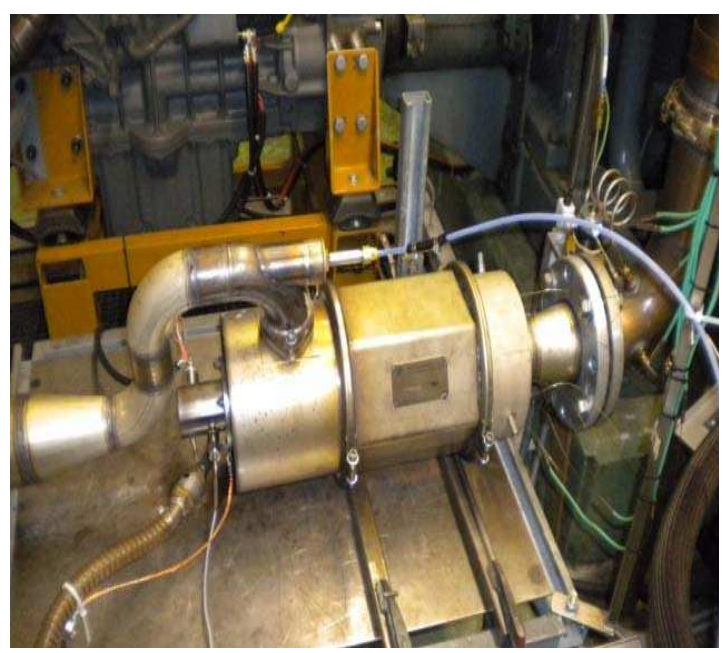

Figure 4 - DPF-system MK with active regeneration (burner) on the Liebherr engine

\section{REGENERATION PROCEDURES \& RESULTS}

According to the objectives each regeneration was performed at least 3 times in an identical test.

The soot loading of the filter is always to the same backpressure ( $\Delta \mathrm{p}=105-115 \mathrm{mbar})$. The chosen DPF sizes were smaller to enable quicker soot loading.

In the entire research program 33 regeneration attempts were conducted. Examples of results from the regenerations listed in Table 5 are given in this paper.

For soot loading the engine was operated dynamically in a rectangular cycle: torque $0-500 \mathrm{Nm}$, speed 800-1100 rpm, period $5 \mathrm{~s}$.

Table 5 - List of presented regenerations

\begin{tabular}{|l|c|l|}
\hline DPF System & Regeneration nbr. & Fuel \\
\hline \multirow{2}{*}{ DOC + CSF } & 7 & B0 \\
& 11 & B20 \\
\hline \multirow{2}{*}{ CSF } & 10 & B100 \\
\hline & 18 & B0 \\
MK & 21 & B20 \\
& 24 & B0 \\
& 25 & B20 \\
\hline & 27 & B20 \\
& 28 & B0 \\
MD & 29 & B0 \\
& 30 & B0 \\
& 31 & B20 \\
\hline
\end{tabular}


During the regeneration procedure several parameters were continuously registered: regulated \& unregulated gaseous emissions (standard \& FTIR), nanoparticles (CPC, PAS, DC) and several temperatures in the filter body. The temperature measuring points in the filter body were distributed along the axis and in radial direction in the exit plane of the filter body, according to experiences of other researchers, $[7,8]$.

\section{PASSIVE REGENERATIONS}

The results of soot loading procedures give important information about the effects of biocomponents.

All loading procedures, except of B100, were performed in identical way. For B100, which yielded very slow soot loading, periodical switch-off's of the engine were applied to cool-down the exhaust system and to minimize the oxidation.
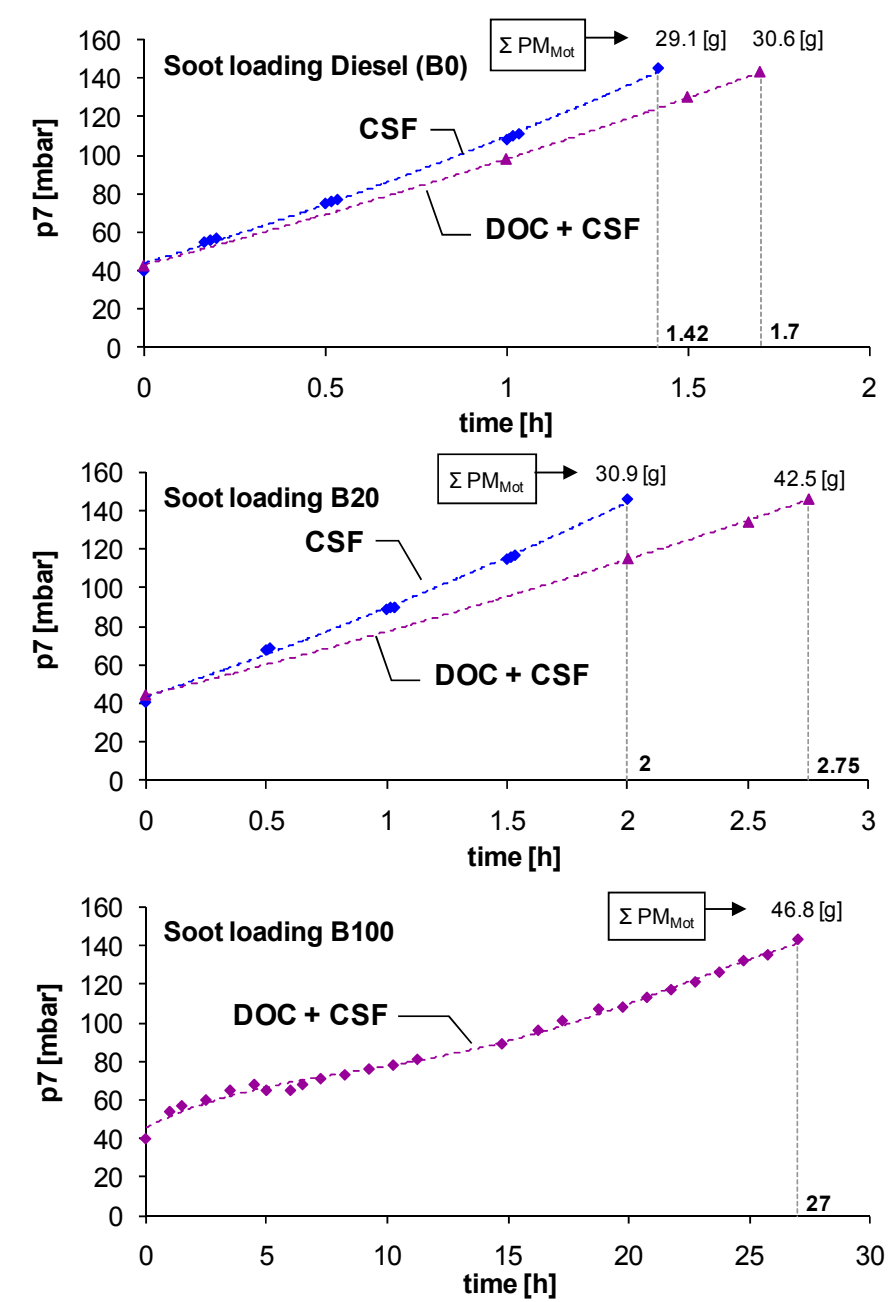

Figure 5 - Backpressure during soot loading cycle

The soot loading with increased bio-content needed always a longer time period. This is represented for (DOC + CSF) and for CSF in Fig. 5.

The final particle mass, as product of engine-out emission and time, increases. Nevertheless the oxidized portion of PM during the soot loading procedure and the PM remaining in the DPF at the end of the soot loading procedure are unknown.

The reasons for slower soot charging with biocomponents are:

- lower engine-out PM-emissions,

- higher reactivity of PM and partial oxidation during soot loading with DOC,

- with high bio-content (here $\mathrm{B} 100$ ) lowering of exhaust gas temperature to the temperature-window of the highest $\mathrm{NO}_{2}$ production in DOC, easier NO-NO 2 oxidation with $\mathrm{B} 100$ and the intensified $\mathrm{NO}_{2}$-continuous regeneration. 
After the soot loading each regeneration attempt was performed in the same way: stepwise increasing of engine torque at a constant speed.
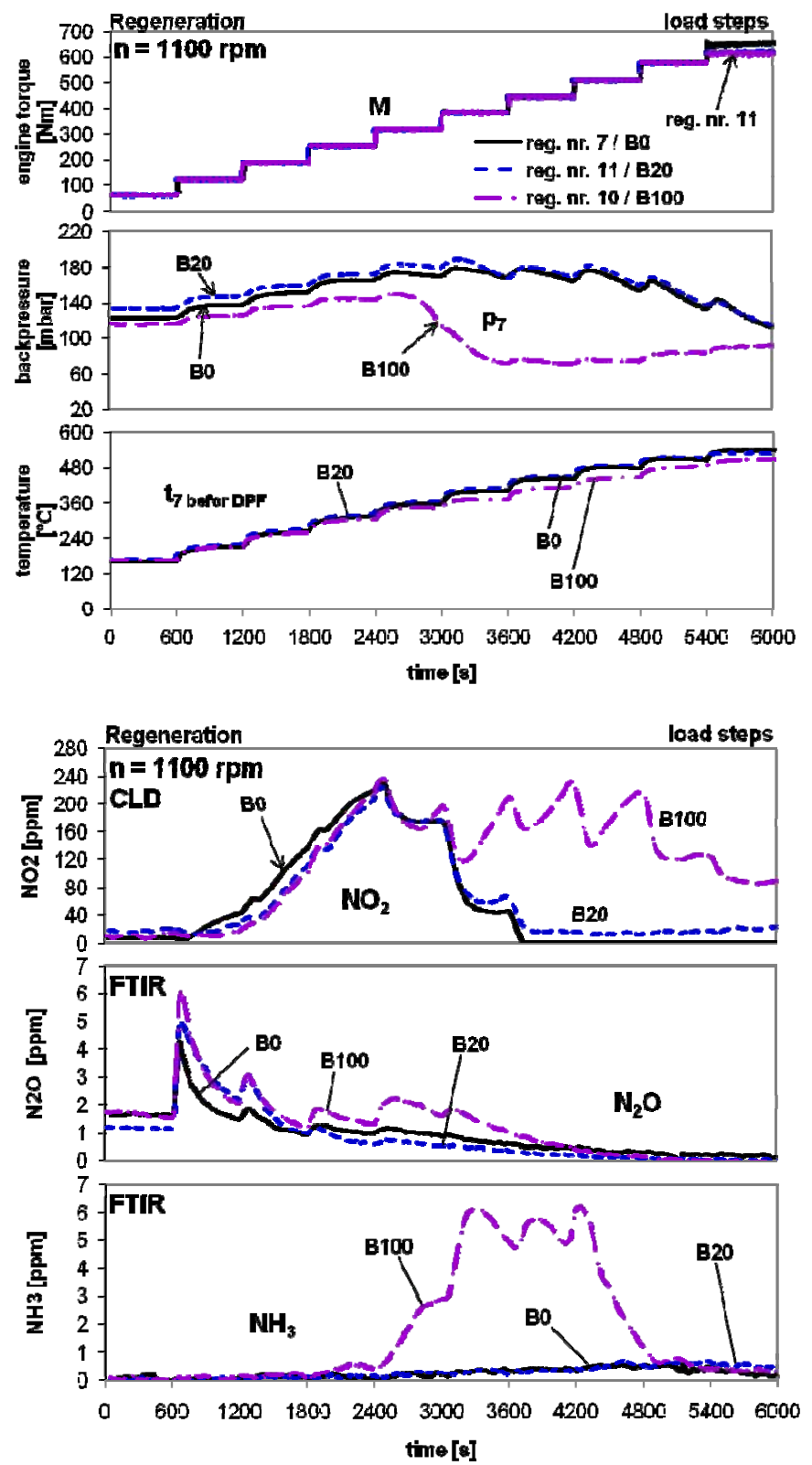

Figure 6 - Regenerations with $(D O C+C S F) \& B 0, B 20 \& B 100$

In Fig. 6 - the comparison of regenerations 7, 11 \& 10 (B0, B20 \& B100 with DOC + CSF) shows with B100 following tendencies, which would not be visible with B20:

- there is more $\mathrm{NO}_{2}$ with $\mathrm{B} 100$ because of lower $\mathrm{t}_{\mathrm{exh}}$ (near to the maximum of $\mathrm{NO}_{2}$-production), more $\mathrm{NO}_{\mathrm{x}}$ and more easy $\mathrm{NO}$ $\mathrm{NO}_{2}$ oxidation,

- the intensity of regeneration with B100 from $5^{\text {th }}$ step (approx. $300^{\circ} \mathrm{C}$ ) is higher; the drop of backpressure quicker than with the other fuels,

- $\quad$ with B100 the $\mathrm{N}_{2} \mathrm{O}$ peak in $2^{\text {nd }}$ step is a little bit higher, than with $\mathrm{B} 20(7 \mathrm{ppm} / 5 \mathrm{ppm})$ and after start of regeneration $\mathrm{NH}_{3}$ increases with B100 up to $6 \mathrm{ppm}$ (during 1/2h), while with B20 it stays at zero-level.

Figure 7 gives the comparisons of the instantaneous NP filtration efficiencies (CPC \& DC) for the test variants with (DOC + CSF) and B0, B20 \& B100. 
With the stronger catalytic system (DOC + DPF) B100 causes a drop of FE during the regeneration because of spontaneous condensation of heavy HC-compounds after DPF and a partially increased break-through of smallest size NP in nuclei mode range.

Fig. 8 - the comparison of regenerations 7, 11 (B0 \& B20 with DOC + CSF) and 18, 16 (B0 \& B20 with CSF) shows for the DPFsystem with weaker catalytic activity (CSF only) following tendencies:

- $\quad$ start of regeneration later - in steps $6 \& 7$ (instead of step 5 like for the other system) at exhaust gas temperature approx. $100^{\circ} \mathrm{C}$ higher,

- $\quad$ higher values of $\mathrm{CO}$ and $\mathrm{HC}$ (less intense oxidation),

- no production of $\mathrm{NO}_{2}$,

- $\quad$ increased NP-values with B20 comparing to B0 (this is not the effect with strongly catalytic system DOC $+\mathrm{CSF}$ ),

- the DPF with DOC oxidizes more the precursor substances of spontaneous condensates yielding lower NP-concentrations since the DOC-light-off is in the $2^{\text {nd }}$ step (approx. $240^{\circ} \mathrm{C}$ ).

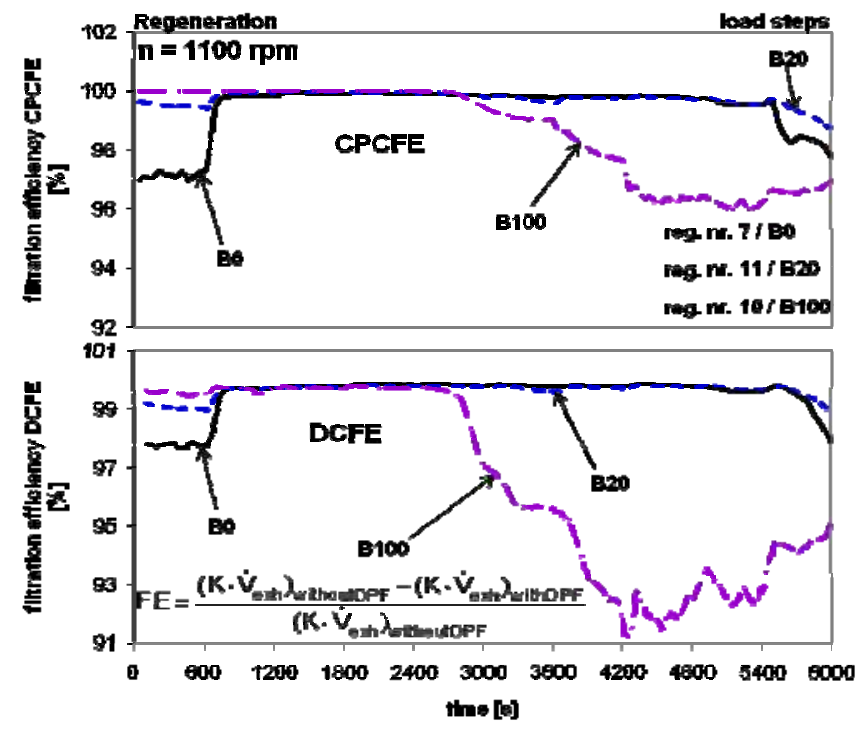

Figure 7 - Instantaneous nanoparticle filtration efficiency during the regeneration procedures with $(D O C+C S F) \& B 0, B 20$, B100
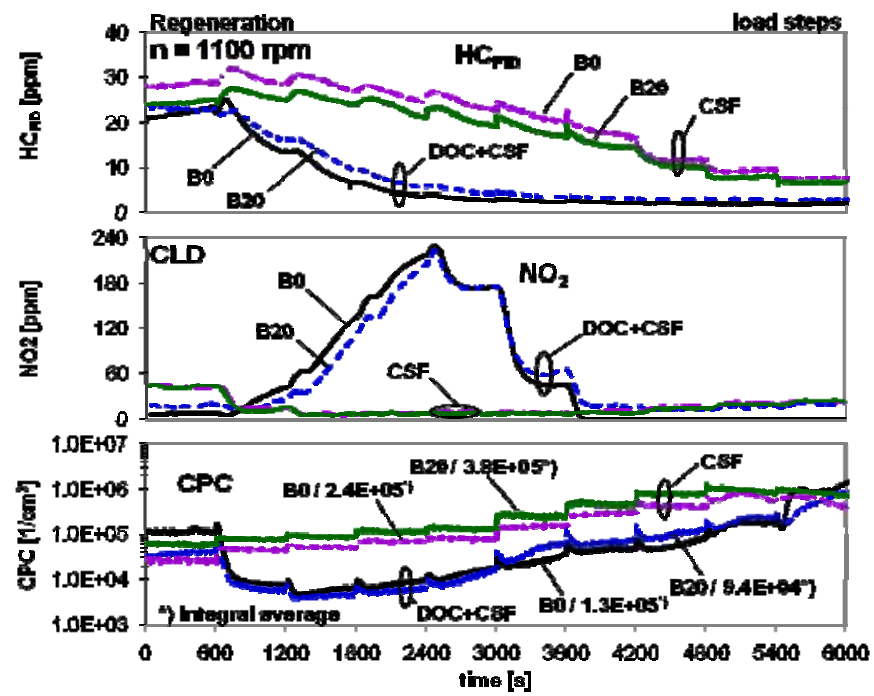

Figure 8 - Regeneration with $(\mathrm{DOC}+\mathrm{CSF})$ vs. $(\mathrm{CSF})$ with $\mathrm{BO} \& \mathrm{~B} 20$ 
Table 6 summarizes the domains of temperatures when the start of backpressure drop is visible in the investigated regeneration variants. There are higher temperatures necessary with less catalytic activity and they decrease with growing bio-content in fuel.

Table 6 - Domains of temperatures with the beginning backpressure drop of the investigated regeneration cases

\begin{tabular}{|l|l|l|}
\hline \multicolumn{3}{|c|}{ DOC + CSF } \\
\hline B0 & B20 & B100 \\
\hline $356-368^{\circ} \mathrm{C}$ & $356-363^{\circ} \mathrm{C}$ & $342^{\circ} \mathrm{C}$ \\
\hline at step 5 & at step 5 & at step 5 \\
\hline \multicolumn{3}{|c|}{$\mathrm{CSF}$} \\
\hline B0 & B20 \\
\hline $454-464^{\circ} \mathrm{C}$ & $447-455^{\circ} \mathrm{C}$ \\
\hline at step 7 & at step 7 \\
\hline
\end{tabular}

Considering entire project results it can be summarized for the tested passive regenerations:

With the same soot loading procedure of $(\mathrm{DOC}+\mathrm{CSF})$ the necessary time to load the DPF for $\Delta \mathrm{p}=$ idem increases with the biocontent of fuel (here for $\Delta \mathrm{p} \approx 100$ mbar: B0 1,7h; B20 2,5h; B100 27h). The reasons for slower soot charging with biocomponents are: lower engine-out PM-emissions and higher reactivity of PM and partial oxidation during soot loading with DOC.

With highest bio-content (here $\mathrm{B} 100$ ) the exhaust gas temperature is lowered to the temperature-window of the highest $\mathrm{NO}_{2}$ production in DOC. This enables an, easier NO- $\mathrm{NO}_{2}$ oxidation with $\mathrm{B} 100$ and the intensified $\mathrm{NO}_{2}$-continuous regeneration. Soot loading with CSF (less intense oxidation activity) takes a little shorter time, than with (DOC+CSF).

With the presence of Pt-coating $(\mathrm{DOC}+\mathrm{CSF})$ there is a production of $\mathrm{NO}_{2}$. With $\mathrm{V}$-coating alone $(\mathrm{CSF})$ there is mostly a reduction of $\mathrm{NO}_{2}$ in the DPF.

The repeatability of regeneration results and of the instantaneous filtration efficiencies is very good, except for the $1^{\text {st }}$ step.

The differences in the $1^{\text {st }}$ step can be explained with the dispersion of the preliminary state of soot loading at the beginning of respective regeneration test.

It was stated by means of curves of instantaneous filtration efficiency and of temperature traces in the DPF-axis, that there is a lower dispersion of successive regeneration procedures with higher content of bio-component.

During the light-off of DOC there is a slight peak of $\mathrm{N}_{2} \mathrm{O}$. This peak is higher with higher bio-content of fuel, which confirms the higher reactivity of the bio-component.

The NP-signals (CPC, PAS, DC) give increased values in the last two steps due to intensified regeneration and higher spacial velocity (increased NP-break-through).

With B100 and with (DOC+CSF) there are some effects, which would not be detectable with B20:

- there is more $\mathrm{NO}_{2}$ with $\mathrm{B} 100$ because of lower $\mathrm{t}_{\mathrm{exh}}$ (near to the maximum of $\mathrm{NO}_{2}$-production), more $\mathrm{NO}_{\mathrm{x}}$ and more easy $\mathrm{NO}$ $\mathrm{NO}_{2}$ oxidation,

- the intensity of regeneration with B100 from $5^{\text {th }}$ step (approx. $340^{\circ} \mathrm{C}$ ) is higher; the drop of backpressure quicker than with the other fuels,

- the increase of NP-emissions due to regeneration with B100 starts in the $4^{\text {th }}$ step - spontaneous condensates after DPF and/or break-through of smallest size NP in nuclei mode range; the result of that is the strongest drop of filtration efficiency during the regeneration with the stronger catalytic system (DOC + DPF) and B100. (The hypothesis is, that the break-through NP give a seeding effect for the post filter spontaneous condensation with aboundance of precursor substances from B100). 


\section{ACTIVE REGENERATIONS}

Standstill burner:

The regeneration procedure with standstill burner (system MK) is represented in Fig. 9. The represented points (1) to (5) are fixed in the ECU of the system and are a repetitive procedure. The air supply by the air pump is an important necessity at engine standstill.

Fig. 10 shows the comparison of regenerations with B0, B20 and B100.

Regeneration 27 (B100) developed too much heat from the burning particle mass (too much SOF accumulated in DPF during soot loading at $\Delta \mathrm{p}$ idem) and destroyed the filter and the thermocouples.

There are tendencies of higher peak value of $\mathrm{NO}_{\mathrm{x}}, \mathrm{NO}_{2}, \mathrm{~N}_{2} \mathrm{O}$ and $\mathrm{NH}_{3}$ with $\mathrm{B} 100$. Nevertheless it must be supposed that some of these results are due to the extreme overheating and not only to the chemistry connected with B100.

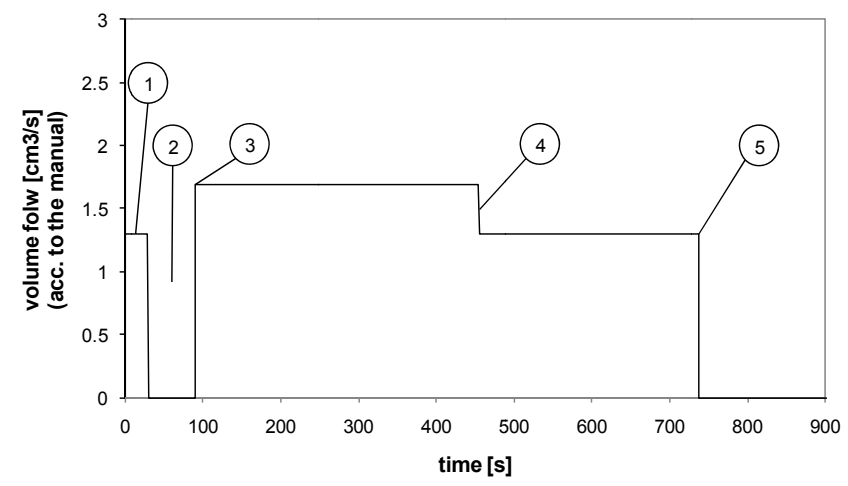

ame

Figure 9 - Regeneration procedure with standstill burner (system MK)
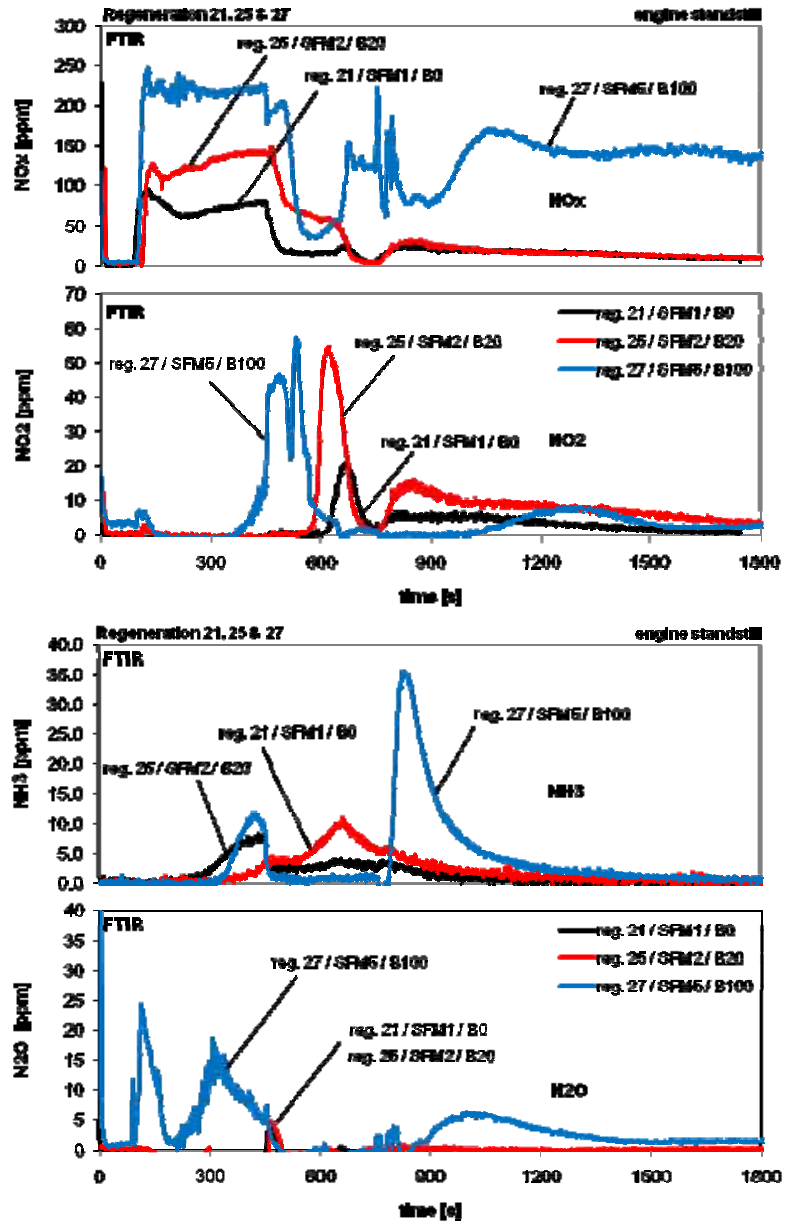

Figure 10 - Influence of B20 \& B100 on the standstill burner regeneration (DPF system MK) 
The DPF overheating with B100 produced a high number of bigger nanoparticles, which increased stronger the summary active surface DC \& PAS, than the count concentrations CPC. This provokes a considerable reduction of the equivalent $\mathrm{FE}_{\mathrm{DC}}$ and $\mathrm{FE}_{\mathrm{PAS}}$, (results not represented here).

A definition of DPF filtration efficiency during engine standstill is not possible, since there is no engine-out emission entering the DPF.

Since the NP-values (CPC, DC \& PAS) were measured during all regeneration procedures it was decided to calculate the instantaneous relative reduction rate of them as an equivalent of filtration efficiency. As reference the average concentrations of CPC, DC \& PAS in the regeneration steps and engine without DPF were considered.

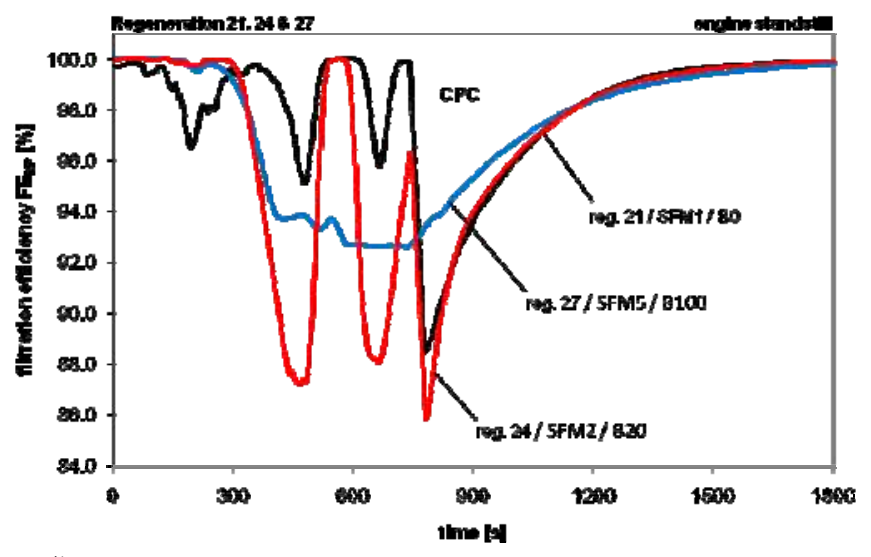

*) all reg. with burner fuel B0 except reg. 24 with B20

$$
F E_{N P}=\frac{(K)_{\text {withoutDPF }}-(K)_{\text {withDPF }}}{(K)_{\text {withoutDPF }}}
$$

Figure 11 - Comparison of instantaneous equivalent CPC-reduction rates during the standstill burner regeneration with different bio-contents (burner fuel BO \& B20)*)

This equivalent filtration efficiency compares only the NP-concentrations $\left[\# / \mathrm{cm}^{3}\right]$. A comparison of absolute particle counts as product of concentration $\left[\# / \mathrm{cm}^{3}\right]$ and volumetric flow $\left[\mathrm{cm}^{3} / \mathrm{s}\right]$ makes no sense, since the volume flow of the regeneration air supply is negligible comparing to the average engine volume flow.

Figure 11 shows some comparisons of instantaneous equivalent CPC- reduction rates with B0 / B20 \& B100. It can be generally remarked, that the nanoparticle penetration during the flame period is stochastically increased - the equivalent filtration efficiency reduced. No influence of bio component content can be remarked.

For the standstill burner regeneration with DPF system MK it can be concluded, that the time-courses of emissions and temperatures are closely connected with the regeneration strategy, i.e. switching on the glow plug and the air \& fuel supply for the burner.

The earlier switch-off of regeneration and air-flow is clearly visible - the soot burning stops.

During the flame period the nanoparticles penetration through the DPF is stochasticall increased.

The biocomponents increase the $\mathrm{NO}_{\mathrm{x}}-\& \mathrm{NO}_{2}$ - values, as well as the probability of higher peak-values of $\mathrm{NH}_{3} \& \mathrm{~N}_{2} \mathrm{O}$ during the regeneration period.

Higher bio-content used as burner fuel can cause more difficult ignition or changed flame intensity of the burner.

The filter loaded quickly with B100 was overheated and destroyed during the regeneration.

Fuel injection and DOC:

The regeneration procedure with fuel injection and DOC (system MD) consists of injecting the same amount of fuel during the same time at a constant operating point of the engine. This operating point can be chosen, but it should be in any case with an exhaust temperature, which is over the light-off of the DOC.

Fig. 12 shows the fuel injection strategies for regeneration of the DPF, system MD. It can be programmed in the ECU of this DPFsystem, that after the first FI-period, if the backpressure does not fall below a certain value, a second FI-period will be automatically activated. 
In the present investigations some regenerations were performed with single, or with double FI.

The $1^{\text {st }}$ two regenerations with each fuel ( $28 \& 29$ with B0; $31 \& 32$ with B20) were performed at engine operating point 900 rpm $/ 250 \mathrm{Nm} / \mathrm{t}_{7}$ approx. $285^{\circ} \mathrm{C}$.

The last regenerations (30 with B0; 33 with B20) were performed at $900 \mathrm{rpm} / 330 \mathrm{Nm} / \mathrm{t}_{7}$ approx. $335^{\circ} \mathrm{C}$.

By engine operation with B0 the same fuel was used for the FI (fuel aerosol generator).

By engine operation with B20 also B20 was used for FI.

Fig. 13 shows a part of the comparison of emissions of regenerations $28,29 \& 30$, all with B0.

The second fuel injection in regeneration 28 is visible by the higher values of temperature before DOC $\left(t_{7 b}\right), C O$ and $\mathrm{HC}$ in the time interval 600-1100s.
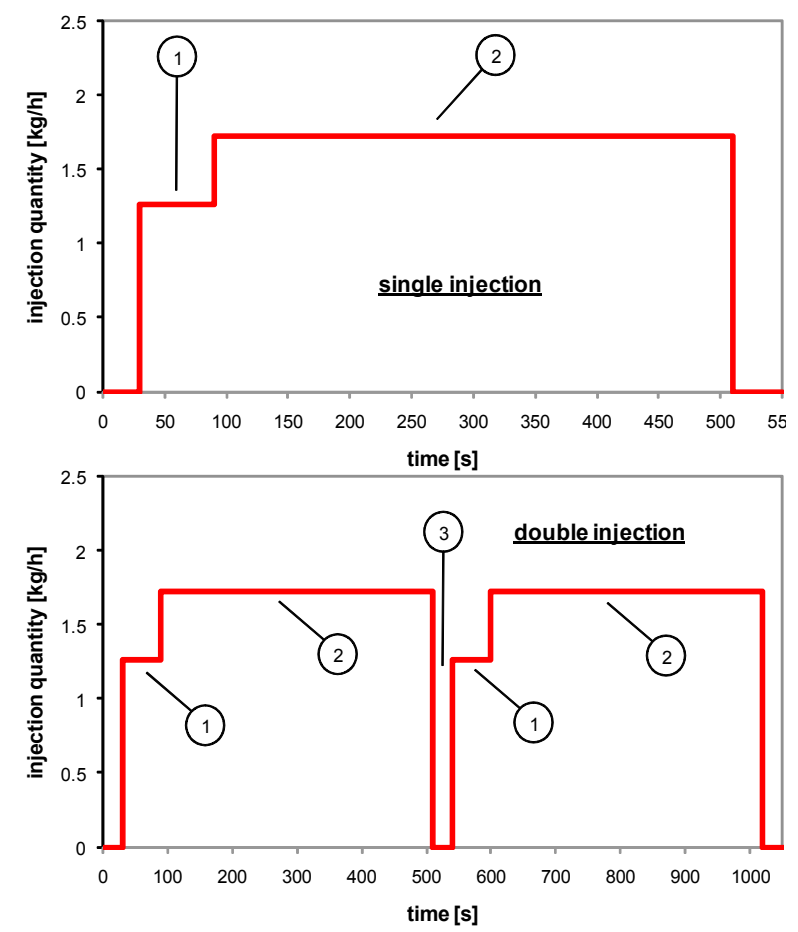

1. preinjection

2. main injection

3. pause

Figure 12 - Fuel injection strategies for regenerations of DPF (system MD)

Regeneration 30 was conducted at higher OP - higher levels of CO, HC and DC in the time interval of FI 200-500s and continuously higher $\mathrm{NO}_{\mathrm{x}}$-values.

After stopping the FI the temperature before DOC $\left(\mathrm{t}_{7 \mathrm{~b}}\right)$ decreased to the range of high $\mathrm{NO}_{2}$-production, which causes a considerable increase of $\mathrm{NO}_{2}$ concentrations. With double $\mathrm{FI}$ (reg. 28) this effect is respectively retarded.

During the fuel injection (FI) there is a production of ammonia $\mathrm{NH}_{3}$ up to $3 \mathrm{ppm}$ and a production of nitrous oxide $\mathrm{N}_{2} \mathrm{O}$ in the range of $10 \mathrm{ppm}$ with considerable peaks (up to $100 \mathrm{ppm}$ ) at the FI-start (not represented here). 


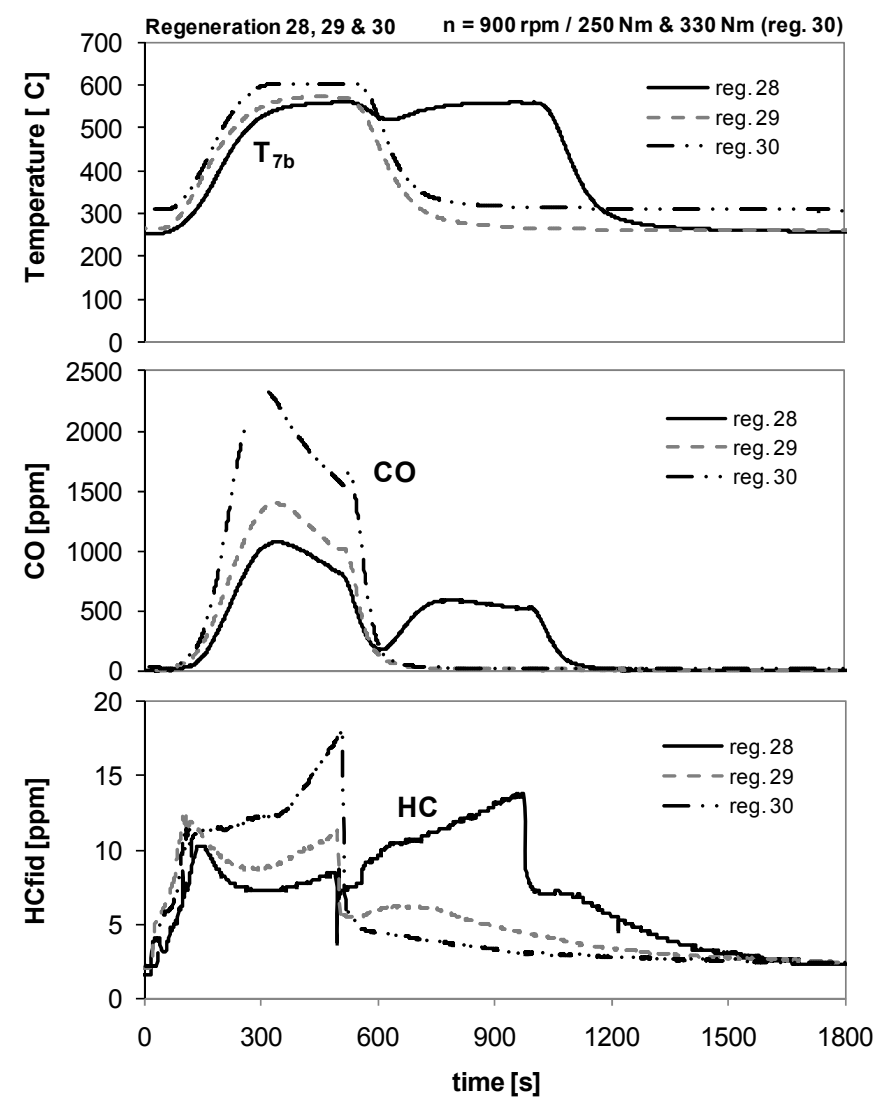

Figure 13a - Fuel aerosol generator regenerations with BO
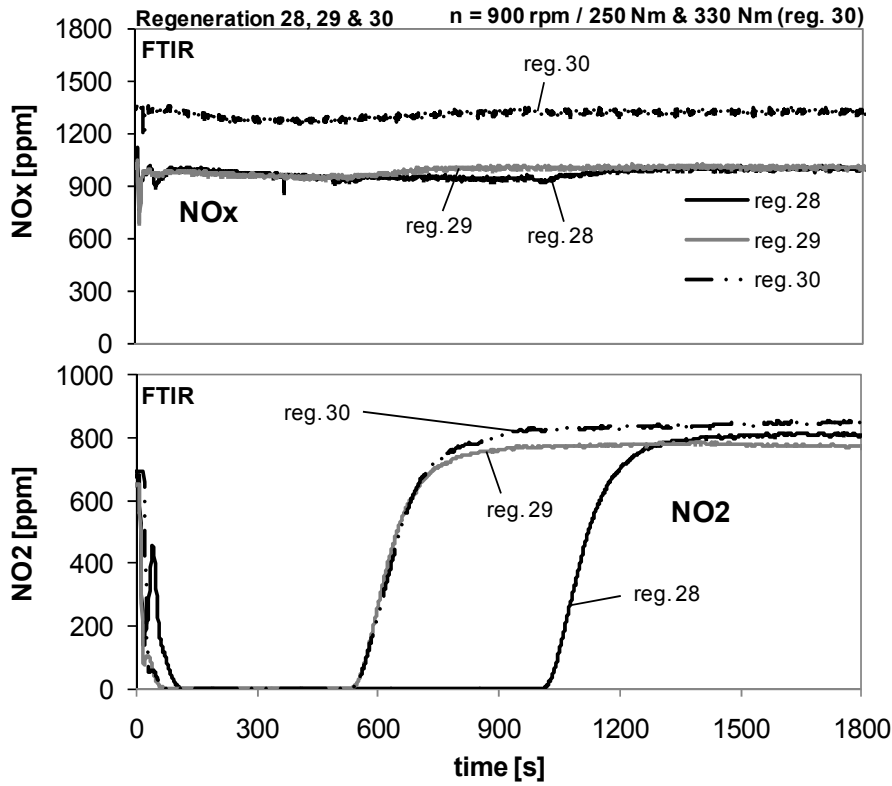

Figure 13b - Fuel aerosol generator regenerations with BO 

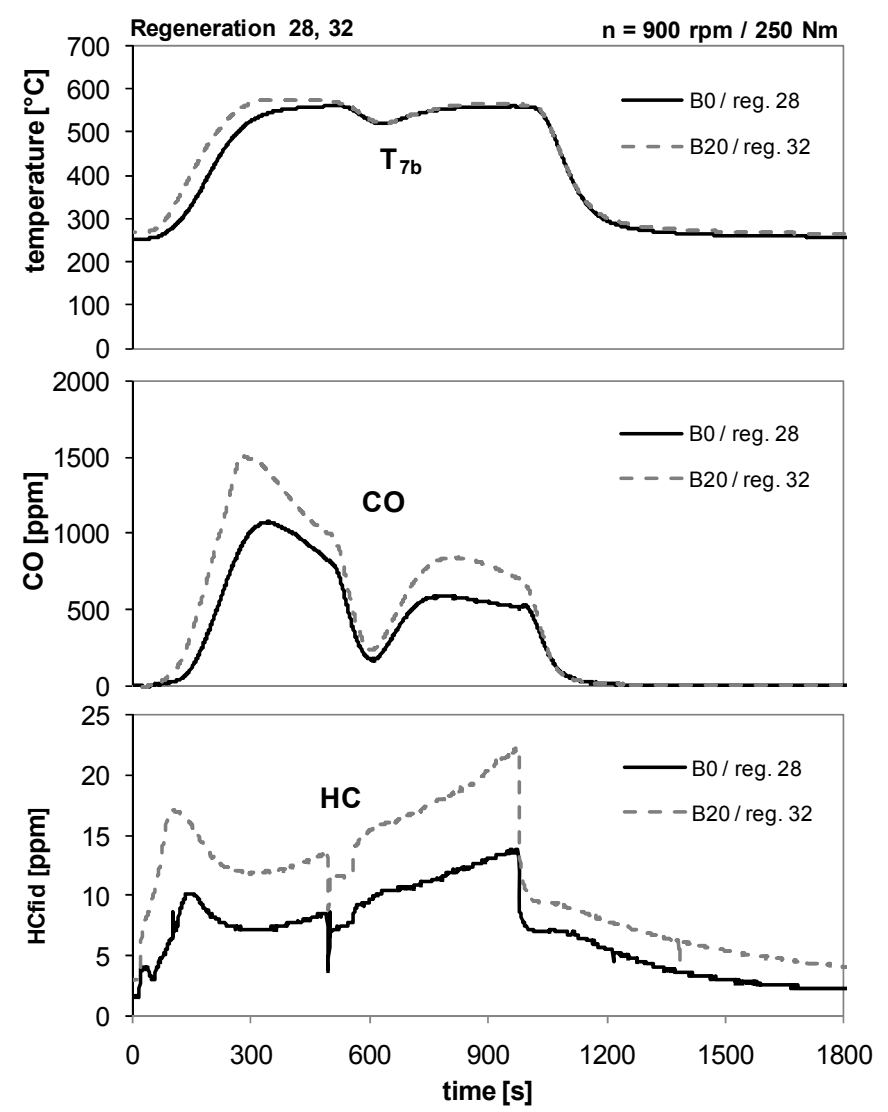

Figure 14 - Influence of B20 on fuel aerosol generator regeneration

Fig. 14 shows the comparisons of some emission parameters with B0 and B20 and with double fuel injection (2xFI).

There are higher $\mathrm{CO}$ and $\mathrm{HC}$ with $\mathrm{B} 20$. There is a little, or no influence of $\mathrm{B} 20$ on $\mathrm{NO}_{\mathrm{x}}, \mathrm{NO}_{2}, \mathrm{~N}_{2} \mathrm{O} \& \mathrm{NH}_{3}$.

In the $1^{\text {st }}$ phase of regeneration process, during the period of increase of the exhaust gas temperature $\left(\mathrm{t}_{7 \mathrm{~b}}\right)$ there are significantly higher NP-emissions with B20; after this period the NP-values become equal, as with B0.

This observation can be explained with the fact, that the fuel injection is also conducted with B20 for the DPF, which was charged with B20. At the beginning of FI, when there is no oxidation in DOC the different HC-matrix from B20 (from both: DOC \& DPF) enables more condensates after DPF. In the further phase, when the oxidation in DOC and in DPF becomes more intense, the influences of the products of this oxidation become similar for both fuels B0 \& B20 and so they give origin to similar condensation effects afterwards.

Fig. 15 represents the comparison of the instantaneous CPC-filtration efficiency B0 \& B20. It is confirmed that with B20 there is a significantly lower CPC FE in the first phase of regeneration procedure up to approx. 700s.

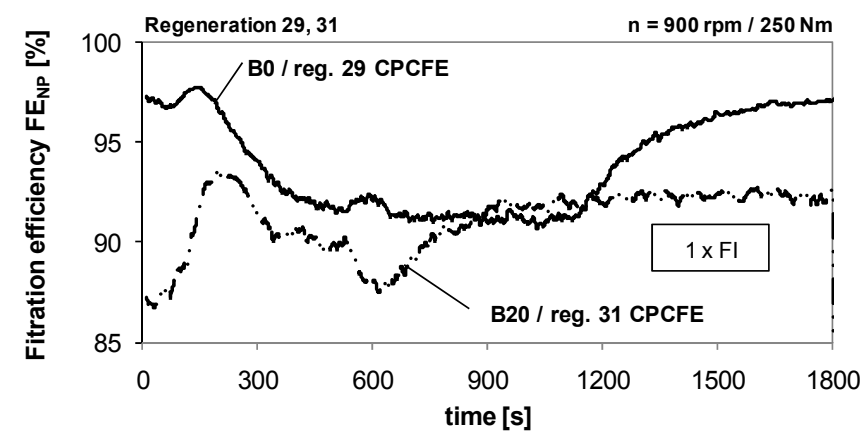

Figure 15 - CPC filtration efficiency during regeneration with $\mathrm{BO} \& \mathrm{~B} 20$

For the regeneration with fuel injection + DOC, DPF system MD it can be summarized, that the longer duration of fuel injection (double FI) prolongs respectively the period of high temperature level for the regeneration and is depicted with the longer period of higher emissions of $\mathrm{CO}, \mathrm{HC}, \mathrm{DC} \& \mathrm{NH}_{3}$ (the last two not represented here). 
After stopping the fuel injection there is an intense production of $\mathrm{NO}_{2}$ due to the exhaust temperature decreasing into the level of $\mathrm{NO}_{2}$-maximum.

During the period of FI there is an insignificant production of $\mathrm{NH}_{3}$ (up to $3 \mathrm{ppm}$ ) and of $\mathrm{N}_{2} \mathrm{O}$ (in the range of 10ppm).

During the regeneration period (period of FI) there is a break-down of NP-filtration efficiency, which correlates with the single, or double FI-period and which is more intense for DC (bigger NP-sizes).

With B20 there is a lower NP-filtration efficiency in the first phase of regeneration procedure - this is an effect of stronger artefact of condensates after DPF, due to the changed HC-matrix of B20.

Comparing the average emission levels of both investigated active regeneration types it can be stated, that the standstill burner has significantly (in 1 range of magnitude) higher $\mathrm{CO} \& \mathrm{HC}$ and lower $\mathrm{NO}_{\mathrm{x}} \& \mathrm{NO}_{2}$, Table 7.

\section{Table 7 - Approximate emission levels during regeneration}

\begin{tabular}{|l|c|c|}
\cline { 2 - 3 } & SOandstill burner & $\begin{array}{c}\text { FI + DOC } \\
\text { const. OP }\end{array}$ \\
\hline $\mathrm{CO}$ & $7000 \mathrm{ppm}$ & $1500 \mathrm{ppm}$ \\
\hline $\mathrm{HC}$ & $200 \mathrm{ppm}$ & $15 \mathrm{ppm}$ \\
\hline $\mathrm{NO}_{\mathrm{x}}$ & $100 \mathrm{ppm}$ & $1100 \mathrm{ppm}$ \\
\hline $\mathrm{NO}_{2}$ & $10 \mathrm{ppm}$ & $500 \mathrm{ppm}$ \\
\hline $\mathrm{NP}$ & $4 \mathrm{E}+051 / \mathrm{cm}^{3}$ & $4 \mathrm{E}+051 / \mathrm{cm}^{3}$ \\
\hline
\end{tabular}

There are surely potentials to improve the emission level of the standstill burner by optimizing the air supply, but the fact of engine standstill remains. This has advantages for lower $\mathrm{NO}_{\mathrm{x}}$ - and $\mathrm{NO}_{2}$ values.

The regeneration procedure with FI+DOC uses the oxygen and the exhaust heat from the engine. The advantages are the lower CO- \& HC-values, nevertheless on the costs of higher $\mathrm{NO}_{\mathrm{x}} \& \mathrm{NO}_{2}$. To mention is the undesired increase of $\mathrm{NO}_{2}$ by switching-off the fuel injection.

The active regeneration systems are very important and sometimes indispensable for certain application profiles of DPF's. They never can be emissions-free and their emissions can be optimized in certain range.

\section{CONCLUSIONS}

The most important results can be summarized as follows:

For the passive regenerations with (DOC+CSF) and with CSF:

- with the same soot loading procedure the necessary time to load the DPF for $\Delta p=$ idem increases with the bio-content of fuel,

- the reasons for slower soot charging with biocomponents are:

- lower engine-out PM-emissions,

- higher reactivity of PM and partial oxidation during soot loading with DOC,

- with presence of Pt-coating and high bio-content (here $\mathrm{B} 100$ ) higher $\mathrm{NO}_{2}$-production in $\mathrm{DOC}$ and the intensified $\mathrm{NO}_{2}$-continuous regeneration,

- soot loading with CSF takes a little shorter time, than with (DOC+CSF),

- the regeneration procedures and emissions are well repeatable and the dispersion of successive regeneration procedures is clearly lowered with higher portion of bio-component.

Research with B100 made it possible to see some effects, which would not be detectable with B20:

$\circ$ more intense $\mathrm{NO}_{2}$-production and more intense regeneration,

- increase of NP-emissions after DPF during the regeneration as result of spontaneous condensates after DPF and/or break-through of smallest size NP in nuclei mode range. 
For the active regeneration with standstill burner:

- the time-courses of emissions and temperatures are closely connected with the regeneration strategy and control of the glow plug and air \& fuel supply to the burner,

- the nanoparticle penetration during the flame period is stochastically increased - the equivalent filtration efficiency reduced,

- the biocomponents increase the $\mathrm{NO}_{\mathrm{x}}-\& \mathrm{NO}_{2}$ - values and the possibility of higher $\mathrm{NH}_{3}-\& \mathrm{~N}_{2} \mathrm{O}$-values during the flame period.

For the semiactive regeneration with fuel injection + DOC:

- longer duration of fuel injection (double FI) prolongs respectively the period of high temperature level for the regeneration and is depicted with the higher emissions of $\mathrm{CO}, \mathrm{HC}, \mathrm{DC} \& \mathrm{NH}_{3}$, in the respective time interval,

- at higher engine operating point of the regeneration there is a higher level of exhaust temperature and of $\mathrm{NO}_{\mathrm{x}}$,

- after stopping the fuel injection there is an intense production of $\mathrm{NO}_{2}$ due to $\mathrm{t}_{\text {exh }}$ decreasing into the level of $\mathrm{NO}_{2}$-maximum,

- during the regeneration period (period of FI) there is a break-down of NP-filtration efficiency, which correlates with the single, or double FI-period and which is more intense for DC,

- with B20 there is a lower NP-filtration efficiency in the first phase of regeneration procedure - this is an effect of stronger artefact of condensates after DPF, due to the changed HC-matrix of B20.

\section{REMARKS AND RECOMMENDATIONS}

The used equipment and procedures in the present project are those of VERT. There are several results concerning the use of biofuels.

Principally the filtration of solid particles (NP) of a DPF is independent of fuel B-content. Nevertheless with increasing share of bio-components there are more condensates after the DPF, which increase the particle count concentrations and simulate the lower overall PC-filtration efficiency (PCFE) of the DPF. This means, that to prevent the mistakes resulting from this artefact it is better to test the DPF with standard fuel.

The soot loading with biofuel, or biofuel-content, needs longer time because of less PM-emission of the engine and also because of stronger soot oxidation during the loading procedure. The regeneration is easier to ignite with biofuel-content. In case of a stronger soot loading up to the limit of the capacity of the DPF, there is a danger of overloading DPF and getting too much heat value of the SOF deposited in the DPF. This effect with B100 caused, in one case of a non-catalytic DPF with an active regeneration help, an overheating and destruction of the filter material.

An important part of VERT quality testing procedure is the field durability test (2000h for VERT, 1000h for LRV). This was not an objective of investigations in the present part of the project, since the results concerning exhaust aftertreatment are well known:

- the biofuels have historically a bad reputation concerning poisoning of catalytic coatings; this is true, if the content of sulphur, phosphorus and dirt is above the quality norm,

- the presence of biofuels quality norms and the fuels, which fulfil these norms are guarantee for satisfactory long life of catalytic coatings,

- the questions of lube oil durability and degradation with application of biofuels is always to consider and it was a subject of several third works.

The fulfilment of biofuel quality requirements depends on supplier, transport, stocks conditions and time of storage.

Bio components have limited durability (validity) time because of oxidative degradation, water absorption and possible bacteria attack $[8,9,10]$. For these reasons the user of biofuel is recommend to periodically control the quality of supply chain and the quality of fuel.

A recently published study of a US industrial consortium, [11], about the impact of biodiesel impurities on the long-term behaviour of exhaust aftertreatment elements showed, that due to diffusion of Alkali Metals $(\mathrm{K}, \mathrm{Na}, \mathrm{Ca})$ into the ceramic materials of DOC, DPF and SCR, the material resistance of these elements is reduced significantly during the long duration operation.

Following recommendations can be given for the use of biofuels with DPF systems:

- the filtration efficiency is not influenced by the biofuel, but there can be artefacts of spontaneous condensates after DPF,

- $\quad$ performing VERT/LRV tests is recommended with a standard fuel, 
- for long life of catalytic coatings and for sustainable engine operation control periodically the quality of fuel and fuel supply chain,

- for active regeneration systems with high bio-content set down the threshold for starting regeneration to the lower values of backpressure, to prevent the danger of overheating of DPF during the regeneration,

- for burner regeneration, if biofuels are used for the burner, make sure the reliable ignition and operation of the burner,

- consider the general recommendation for the engine: durability of injection system and of lube oil; power reduction with fuels with lower heat value; limits of electronic regulation with changed heat value of fuel.

\section{ACKNOWLDEGEMENTS}

The authors want to express their gratitude for the financial support and realisation of the project to the:

- Swiss Federal Office of Environment BAFU, Mr. F. Reutimann,

- $\quad$ Swiss Federal Office Energy, Mr. M. Pulfer

- Swiss Oil, Erdölvereinigung, Mr. A. Heitzer

Further thanks are expressed to:

- HUG AG, Mr. Ch. Hug

- HUSS GmbH, Mr. H-J. Rembor

for supplying the test material and the expertise of DPF regeneration systems

\section{REFERENCES}

[1] Boehman, A.L.; Song, J.; Alam, M.: Impact of Biodiesel Blending on Diesel Soot and the Regeneration of Particulate Filters. Energy \& Fuels 2005, 19, 1857-1864.

[2] Song, J.; Alam, M.; Boehman, A.L.; Kim, U.: Examination of the oxidation behavior of biodiesel soot. ScienceDirect, Combustion and Flame 146 (2006) 589-604.

[3] Williams, A.; McCormick, R.L.; Hayes, R.R.; Ireland, J.; Fang, H.L.: Effect of Biodiesel Blends on Diesel Particulate Filter Performance. SAE Technical Paper 2006-01-3280. SAE Internatioanl, Powertrain \& Fluid Systems Conference \& Exhibition, Toronto, Canada, October 16-19, 2006.

[4] Zabetta, E.C.; Hupa, M.; Niemi, S.: Bio-derived fuels may ease the regeneration of diesel particulate traps. Elsevier, Fuel 85 (2006) 2666-2670.

[5] Bach, F.; Tschöke, H.; Simon, H.: Influence of Alternative Fuels on Diesel Engine Aftertreatment. TAE Technische Akademie Esslingen, $7^{\text {th }}$ International Colloquium „Fuels“, January 2009, p. 685.

[6] Mizutani, T.; Watanabe, Y.; Yuuki, K.; Hashimoto, S.; Hamanaka, T.; Kawashima, J.: Soot Regeneration Model for SiCDPF System Design. SAE Paper 2004-01-0159.

[7] Chilumukuru, K.; Arasappa, R.; Johnson, J. H.; Naber, J. D.: An Experimental Study of Particulate Thermal Oxidation in a Catalyzed Filter During Active Regeneration. SAE Paper 2009-01-1474

[8] Ullman, J.; Eppinger, D.; Stutzenberger, H.; Straub, G.: Factors Influencing Fuel Ageing - Conclusions from Laboratory Experiments and Investigations in Vehicle. $8^{\text {th }}$ International Colloquium "Fuels", TAE - Technische Akademie Esslingen, Jan. 2011, ISBN 3-924813-86-8, p. 99

[9] Karavalakis, G.; Karonis, D.; Zannikos, F.; Stournas, S.: Evaluation of the Oxidation Stability of Diesel/Biodiesel Blends. $8^{\text {th }}$ International Colloquium "Fuels", TAE -Technische Akademie Esslingen, Jan. 2011, ISBN 3-924813-86-8, p. 109

[10] Jansson, R.: Microorganisms Will Always be There, Waiting for the Next Opportunity to Proliferate. $8^{\text {th }}$ International Colloquium "Fuels", TAE - Technische Akademie Esslingen, Jan. 2011, ISBN 3-924813-86-8, p. 119

[11] Williams, A.; McCormick, R.; Luecke, J.; Brezny, R.; Geisselmann, A.; Voss, K.; Hallstrom, K.; Leustek, M.; Parsons, J.; Abi-Akar, H.: Impact of Biodiesel Impurities on the Performance and Durability of DOC, DPF and SCR Technologies. SAE Techn. Paper 2011-01-1136, SAE World Congress, Detroit April 12 $2^{\text {th }}-14^{\text {th }}, 2011$.

\section{ABBREVIATIONS}

$\begin{array}{ll}\text { AFHB } & \text { Abgasprüfstelle FH Biel, CH } \\ \text { Air min } & \text { stoichiometric air requirement } \\ \text { BAFU } & \text { Bundesamt für Umwelt, (Swiss EPA) } \\ \text { BfE } & \text { Bundesamt für Energie } \\ \text { CFPP } & \text { cold filter plugging point } \\ \text { CLD } & \text { chemiluminescence detector } \\ \text { CPC } & \text { condensation particle counter } \\ \text { CSF } & \text { catalyzed soot filter } \\ \text { DC } & \text { Diffusion Charging sensor } \\ \text { DI } & \text { Direct Injection }\end{array}$




$\begin{array}{ll}\text { DPF } & \text { Diesel Particle Filter } \\ \text { DMA } & \text { differential mobility analyzer } \\ \text { ECU } & \text { electronic control unit } \\ \text { EMPA } & \text { Eidgenössische Material Prüf- und Forschungsanstalt, CH } \\ \text { FAME } & \text { fatty acid methyl ester } \\ \text { FE } & \text { filtration efficiency } \\ \text { FI } & \text { fuel injection } \\ \text { FID } & \text { flame ionization detector } \\ \text { FL } & \text { full load } \\ \text { FOEN } & \text { Federal Office of Environment (BAFU), CH } \\ \text { FT } & \text { Fischer Tropsch } \\ \text { FTIR } & \text { Fourier Transform Infrared Spectrometer } \\ \text { HD } & \text { heavy duty } \\ \text { ICE } & \text { internal combustion engines } \\ \text { LRV } & \text { Luftreinhalteverordnung, CH (OAPC) } \\ \text { MD19 } & \text { heated minidiluter } \\ \text { NanoMet } & \text { nanoparticle summary surface analyser (PAS+DC+MD19) } \\ \text { NDIR } & \text { nondispersive infrared } \\ \text { NP } & \text { nanoparticles }<\text { 999 nm (SMPS }- \text { range) } \\ \text { OAPC } & \text { Ordinance on Air Pollution Control } \\ \text { OEM } & \text { original equipment manufacturer } \\ \text { OP } & \text { operating point } \\ \text { PAH } & \text { Polycyclic Aromatic Hydrocarbons } \\ \text { PAS } & \text { Photoelectric Aerosol Sensor } \\ \text { PC } & \text { particle counts } \\ \text { PCFE } & \text { particle counts filtration efficiency } \\ \text { PM } & \text { particulate matter, particle mass } \\ \text { PMFE } & \text { particle mass filtration efficiency } \\ \text { PN } & \text { particle number } \\ \text { PSD } & \text { particle size distribution } \\ \text { RME } & \text { rapeseed oil methyl ester } \\ \text { SMPS } & \text { Scanning Mobility Particle Sizer } \\ \text { SOF } & \text { soluble organic fraction } \\ \text { TC } & \text { thermoconditioner, Total Carbon } \\ \text { TTM } & \text { Technik Thermische Maschinen, CH } \\ \text { ULSD } & \text { ultra low sulfur Diesel } \\ \text { VERT } & \text { Verification of Emission Reduction Technology } \\ \text { xTL } & \text { www.vert-certification.eu } \\ \text { x to liquid (x: B/G/C) } \\ \end{array}$

